\title{
An Analysis of the Status Quo of Energy Utilization and Countermeasures in China
}

\author{
Xiaohong Zhang, Ruichao Zhu, Xin Li \& Shouli Chen \\ School of Economics and Management, Beijing Institute of Petrolchemical Technology \\ Beijing 102617, China
}

This article is funded by energy efficiency management evaluation and innovation research team (Project No. PHR201007136), academic innovation talent project (Project No. PHR201006132), young key personnel project (Project No. PHR201008354) of Beijing Institute of Petrochemical Technology.

\begin{abstract}
With China's rapid economic development and the world's total primary Energy declining, Energy bottleneck effect on China's economy has become increasing evident. China's economic growth pattern is in the transitional period from extensiveness to intensiveness, the improvement of the energy structure also becomes more urgent. In this paper, the authors put forward some measures to adjust China's energy structure through the analysis of the status quo of China's energy structure and the existing problems. To achieve the sustainable development of energy, economics and environment, we must accelerate the transformation of China's energy structure, and strengthen publicity and promote healthy lifestyles.
\end{abstract}

Keywords: Energy, Structure, Utilization efficiency, Current situation, Countermeasures

1. Introduction

As the driving force of economic development, energy plays an indispensable role in today's world politics and in the economical stage. The rapid growth of whole world energy demand directly results in the absolute reserves of global primary energy decreased; mass emissions of $\mathrm{CO}_{2}, \mathrm{SO}_{2}$ from large consumption of primary energy accelerates the process of global warming; international oil price instability and other issues induced by energy security and geopolitical factors are threatening the economic growth. The 21 st century has entered a "post-OPEC era"(He Jun. 2003) definitely. Based on the above reasons, most countries reconsider the 90's economic policies, such as the EU's Green Paper of European Union (CEC2000), the United States energy planning (UNPAG2001) and so on.

The first two decades of the 21 st century will be the golden period of economic growth in China. According to the goal of the comprehensive construction of a well-off society put forward by the Seventeen National Party Congress, the total GDP of our country will quadruple that of 2000 by 2020. In today with global economic integration agenda speeding up, the claims of environmental protection becoming louder and energy security being very unstable, energy issues have received wide attention around the world. Compared with developed countries, industrialization in China started late, the degree of development are far from perfect and the challenges of China's energy problems are also very great. According to the basic national conditions of China's energy, economic growth in China depends on stable supply of coal for a long period. In recent years, the negative impact of absolute principal of coal in energy structure on China's economic growth gradually increases, environmental issues and the problem of energy utilization efficiency have become prominent, so to solve the deep-rooted problems of energy structure is imminent.

From table 1, our long-term trend for energy consumption is gradually increasing, and the range is bigger in recent years. On the other hand, the proportion of coal use is about $70 \%$. For recognized clean energy such as the oil and gas, their proportion in energy use needs to be improved, which plays an important role in improving the energy structure. Improvement of energy structure is mainly dependent on the rich energy sources, so improving the proportion of clean energy and renewable energy in the whole energy is an effective way to solve the problem of environmental degradation and accelerating economic growth mode transformation.

\section{China's energy utilization status quo and problems}

China is in a stage of rapid economic development and accelerating the transformation of the energy structure will put China's economic growth in a more favorable position. In today with world energy environment having drastic changes, how to maximize the utilization of resources has become another subject of new era. Judging from the energy consumption structure, coal resources is in absolute position in China's energy system, oil, natural gas and some renewable resources is in the upward trend significantly in the proportion of energy use; viewing from the aspect of energy utilization efficiency, China's ten thousand yuan GDP energy consumption has reduced year by year, but there is still a big gap compared to developed countries.

In recent years, our country has invested a great deal of human material and financial resources in improving energy utilization efficiency and developing renewable energy, and has achieved some encouraging results. Take Beijing for example, its energy utilization efficiency improves year after year, the whole city's ten thousand yuan GDP energy consumption fell from 0.8 tons of standard coal in 2005 to 0.6619 tons of standard coal in 2008, decreased by $17.26 \%$ (Huang yi, Zhang Yongjuan. 2007). Energy development and energy conservation plan of 
Beijing in" Eleventh Five-Year "period put forward: by 2010, the total energy consumption will be controlled in about 65 million tons of standard coal, the proportion of high-quality energy in energy consumption structure reaches $70 \%$ or more, which new energy and renewable energy will try to reach $4 \%$. Beijing's energy mainly relies on transferred from the outside world, so we can see that the high-quality energy (mainly point at oil and gas) account for a high proportion in Beijing. In terms of the whole country, the proportion of the use of coal is declining year by year. In 2008, clean energy and renewable energy use accounts for $31.3 \%$ of the total, but compared to the target of Beijing in 2010, the gap is quite great far from the degree of development of Beijing. For the reasons, China is primarily a country with relative shortage of oil and natural gas but relatively rich coal resources, which directly leads to relatively cheap coal resources. But as a rational manager who pursuits the maximum profit, the inevitable choice is coal; Secondly, as one of the pioneer cities of energy structure transformation, its energy supply is relatively abundant, and the energy supply structure is relatively optimum. For many small and medium sized cities, the process to improve the proportion of clean energy in energy use such as Beijing is inevitable. Energy structure transformation also means gradually enriching the proportion of non-coal resources in energy use, which is so-called energy structure adjustment.

1) Coal

As the basic national conditions of China's energy use, coal has been as China's first energy for a long time. From table 1, we can see the direct use of raw coal in the use of all coal resources accounts for a great proportion. The great deal of $\mathrm{CO}_{2}, \mathrm{SO}_{2}$ emissions have accelerated the worsening of climate, increased pollution control cost, so it can be said that the use of raw coal in China is still in a directly use stage. In terms of the world, coal is usually considered a relatively unclean energy. Compared with developed countries, China's coal use efficiency is significantly lower and the deep-processing industry technology of raw coal is relatively incomplete. Based on the important position of coal in China's energy, energy transformation relies mainly on deep-processing of coal. Deep-processing of coal means energy consumption will increase when producting cleaner coal, so how to minimize losses needs the industry's own reform and the concept of green chemical industry.

China is has abundant storage and distribution. According to statistics, there are 1,458 counties (cities and counties have more than 2300 in China) having coal storage, but in the area of north of Qinling Mountain Huaihe River holds $90 \%$ of the reserves distribution, especially in these three provinces such as Shanxi, Shanxi and Inner Mongolia, whose total coal reserves account for $63.5 \%$ of the whole country's coal reserves. Viewed from the east-west direction, $85 \%$ of the coal located in the Midwest, but only $15 \%$ in the coastal areas. In the comparatively poor region of coal resources there are relatively rich provinces, such as the northeastern Heilongjiang province, eastern China's An'hui province, central China's Henan province; but in the comparatively affluent region of energy there are also relatively poor provinces, such as the northwestern Gansu Province, north China's Beijing and Tianjin. Viewed from the proved reserves of each province, more than 100 billion tons are in Shanxi, Shaanxi, Inner Mongolia; $20 \sim 100$ billion tons are in Xinjiang, Guizhou, Ningxia, Anhui, Yunnan and Henan six Provinces, together accounting for $25.3 \%$ of the whole country(Zhao Liurong,Tian Lixin. 2008). From the above data, the geographical distribution of coal is extremely uneven, mainly reflecting a "north Coal south transport" trend. The uneven distribution of coal producing area and coal demand area directly results in coal transport increase, which has a certain effect on timely and effectively using energy.

2) Oil and natural gas

China's oil and natural gas reserves are relatively less. Based on continuous growth in energy demand in recent years and urgent need of deep-seated improving the energy structure, import dependence of China's oil and natural gas significantly has increased obviously, China has become the world's second largest energy consumer, and the influence on world oil market is gradually increasing.

The oil-importing countries of China relatively concentrate on five countries including Saudi Arabia, Angola, Russia, Iran and Oman. From the above several countries crude oil imports are higher than 10 million tons, that is, China's oil security problem is easily controlled by others. In recent years, instability in the Middle East, so energy security is broadly concerned. According to China's current economic growth rate, there is still great potential for imports of oil and natural gas. To improve the energy structure certainly will increase oil and natural gas imports. Therefore, promoting the diversification of oil imports becomes the first issue for China to consider.

\section{3) Renewable energy}

Research on renewable energy will bring considerable economic benefits. About 400 million people in China still rely on traditional biomass energy for cooking and heating. According to IEA estimates, consumption of firewood is about 200 million tons of standard coal each year. Biomass energy as renewable energy has been widely recognized worldwide, most notably are Brazil and the EU.

Energy developing in the direction of green renewable has become the general trend of the world's energy financial markets. According to the International Energy Agency predicts that by 2020, the global use of renewable resources will account for 30\% of all energy but the percentage of China's new energy and renewable energy in all of the of energy use is only about 7\% at present(Li, Jinfeng, 2008). "The medium and long term Renewable Energy Development Plan" proposed that renewable energy in China will account for over 16\% of 
primary energy consumption up to 2020 . The total is equivalent to 600 million tons of standard coal, which will benefit China's energy structure adjustment and ensure energy security.

The main representatives of renewable energy use are hydropower, nuclear power and wind power. In terms of cost, small hydropower generation cost is about 1.2 times of coal, biomass power generation cost is 1.5 times of coal, wind power generation cost is 1.7 times of coal (Cai, Lu \& Yan, Xiaofei. 2009). The high cost of renewable energy is the main reason for restricting the development of this industry. On the other hand, China's renewable energy is still at the initial stage, technology is relatively lagging behind other countries and the required research funds for scientific research is also considerable. In general, the use of renewable energy needs longtime endeavors.

\section{Specific measures to adjust the energy structure}

To realize the sustainable development of energy, economy and environment, we must accelerate the transformation of China's energy structure, promote the use of clean resources, encourage the development of renewable energy, strengthen publicity, and advocate healthy lifestyles.

\subsection{Promote the use of clean resources}

The dominant position of coal in China's energy structure has brought greatly negative impact to environmental protection in China for a long time. Compared with coal, oil use efficiency is $23 \%$ higher than coal and natural gas use efficiency is $30 \%$ higher than coal(Yang, Zhanshu \& Qu, Weiguo. 2009), which are more high-quality energy. As top priority of energy structure transformation, when conditions permit, China should actively conduct international cooperation in energy, import more high-quality energy from the outside world. In addition, our current coal in the overall energy use accounts for about $70 \%$, which is similar to industrial countries in 1970s. Viewing from the point of historical development, it is difficult for China to avoid the problem at this stage that coal's position declines in energy structure. Therefore, carrying out international exchanges is also conducive to absorbing advanced foreign management experience, and thus gain double ultimate effects.

\subsection{Enhance energy utilization technology.}

Enhancing the technology of energy use is the most effective way to solve our energy problem. In recent years, United States' proportion of coal in energy structure increases gradually and Germany's coal deep-processing technology also contributes to the improvement of its coal utilization(Deng, Zhir \& Fan, Decheng, 2009). The fact shows that after coal utilization technology is mature, it has potential to become a kind of environment-friendly energy so as to effectively alleviates the shortage of oil and natural gas, and provide powerful support for the sustainable development of economy.

\subsection{Encourage the development of renewable energy.}

Renewable energy as the follow-up energy has become the consensus of the world. China has abundant renewable energy resources: developable water resources is 378 million KW but the part which currently already been developed and used is only 11\%; biomass energy reached a total of 2.6 billion tons of standard coal; wind energy resources that can be developed and used reaches 160 million KW; at present the total geothermal energy that has been explored reaches amazing 462.6 billion tons of standard coal, but now the part which has already been used accounts for only one among hundred thousandth or so (Li, Pengbo, 2008). Development of renewable energy can bring enormous economic benefit for China, and to obtain sustainable supply of follow-up energy should increase investment in the earlier stage, and it is inevitable to increase efforts to develop renewable energy sources.

\subsection{Strengthen publicity and advocate green life}

In the end of energy, waste are common phenomena and some very useful energy-saving common sense is often overlooked by people, such as using energy-saving light bulbs, direct combustion of biomass energy and so on. Transformation in energy structure is historic mission of later energy era. China, as a country with large population, transformation in energy structure needs the whole society's joint efforts.

\section{Conclusion}

Traditional energy use exist the problems of resource waste and environmental pollution, which is no longer applicable to the needs of our intensive growth. The world's total investment in clean energy industries was only 33 billion dollars in 2002, but reached 140 billion dollars in 2007, increased by 60\% than 2006. In 2009 Davos forum predicts that the total investment of global clean energy industry will reach 450 billion dollars in 2012, and exceed 600 billion dollars in 2020. Transformation in energy structure will accelerate transformation of China's economic structure, so that China's economic growth can achieve the goal of sustainable development.

\section{References}

Cai Lu,Yan Xiaofei. (2009). Study on current situation of renewable energy and its problem in China [J]. Consumer Guide publication. 2009, (6):46-47.

Deng Zhiru, Fan Decheng. (2009). Research on China's energy structure problems and its Solutions[J]. Modern Management Science, 2009(6):84-85. 
He Jun. (2003). Global will face an era with no OPEC. Sohu Anbang Finance Forum. http://business.sohu.com/49/05/article210890549.shtml.2003.07.09.

Huang yi, Zhang Yongjuan. (2007). Energy consumption status in Beijing and comparative analysis of domestic and foreign [J]. Data, 2007, (1-2):24-25.

Li Jinfeng. (2008). China's energy resource industrial structure and the adjustment and optimization of [D], Coal, 2008(4):1-6.

Li Pengbo. (2009). Research on China's energy efficiency and the relationship between consumption and economic growth [D]. Master's degree thesis of Capital Economic and Trade University.2009,(5):4-5.

Yang Zhanshu, Qu Weiguo. (2009). Research on policy about optimizing the energy structure of China[J]. China's development. 2009, (2):24-27.

Zhao Liurong, Tian Lixin. (2008). Adjustment of energy structure and energy strategy study [J]. Master's degree thesis of Jiangsu University, 2008(12):6-7.

Table 1. Gross energy consumption and composing in China

\begin{tabular}{|c|c|c|c|c|c|}
\hline \multirow[b]{2}{*}{ Year } & \multirow{2}{*}{$\begin{array}{l}\text { Gross energy } \\
\text { consumption /Ten } \\
\text { thousand tons of } \\
\text { standard coal }\end{array}$} & \multicolumn{4}{|c|}{$\begin{array}{l}\text { Composing (According to } 100 \% \text { of gross } \\
\text { energy consumption) }\end{array}$} \\
\hline & & Coal & Oil & $\begin{array}{l}\text { Natural } \\
\text { gas }\end{array}$ & $\begin{array}{l}\text { Primary } \\
\text { electric } \\
\text { power }\end{array}$ \\
\hline $\begin{array}{l}1975 \\
\text { year }\end{array}$ & 57144 & 70.67 & 22.73 & 3.20 & 3.40 \\
\hline $\begin{array}{l}1980 \\
\text { year }\end{array}$ & 60275 & 72.15 & 20.76 & 3.10 & 3.99 \\
\hline $\begin{array}{l}1985 \\
\text { year }\end{array}$ & 76682 & 73.81 & 17.10 & 2.24 & 4.85 \\
\hline $\begin{array}{l}1990 \\
\text { year }\end{array}$ & 98703 & 76.20 & 16.60 & 2.10 & 5.10 \\
\hline $\begin{array}{l}1995 \\
\text { year }\end{array}$ & 131176 & 74.60 & 17.50 & 1.80 & 6.10 \\
\hline $\begin{array}{l}2000 \\
\text { year }\end{array}$ & 138553 & 67.75 & 23.21 & 2.35 & 6.69 \\
\hline $\begin{array}{l}2001 \\
\text { year }\end{array}$ & 143199 & 66.48 & 22.97 & 2.55 & 7.90 \\
\hline $\begin{array}{l}2002 \\
\text { year }\end{array}$ & 151797 & 66.32 & 23.41 & 2.56 & 7.71 \\
\hline $\begin{array}{l}2003 \\
\text { year }\end{array}$ & 174990 & 66.38 & 22.21 & 2.58 & 6.83 \\
\hline $\begin{array}{l}2004 \\
\text { year }\end{array}$ & 203227 & 67.99 & 22.33 & 2.60 & 7.08 \\
\hline $\begin{array}{l}2005 \\
\text { year }\end{array}$ & 224682 & 69.10 & 21.00 & 2.80 & 7.10 \\
\hline $\begin{array}{l}2006 \\
\text { year }\end{array}$ & 246270 & 69.40 & 20.40 & 3.03 & 7.17 \\
\hline $\begin{array}{l}2007 \\
\text { year }\end{array}$ & 265583 & 69.50 & 19.70 & 3.50 & 7.30 \\
\hline $\begin{array}{l}2008 \\
\text { year }\end{array}$ & 285000 & 68.70 & 18.70 & 3.80 & 8.80 \\
\hline
\end{tabular}

Note: primary electric power includes hydropower, nuclear power and the other renewable energy power

Data source: National Bureau of Statistics. “China Statistical Yearbook”(2009). 